\title{
Freeman-Sheldon Syndrome Associated with Hemophilia-A in a Newborn
}

\author{
Bir Yenidoğanda Freeman-Sheldon Sendromunun Hemofili A ile Birlikteliği \\ Bilge Tanyeri Bayraktar, Süleyman Bayraktar*, Hüseyin Arslan**, Fatma Betül Çakır*** \\ Bezmialem Foundation University Faculty of Medicine, Department of Neonatology, Istanbul, Turkey \\ *Haseki Training and Research Hospital, Clinic of Pediatrics, istanbul, Turkey \\ ${ }^{* *}$ Medipol University Faculty of Medicine, Department of Pediatrics, Istanbul, Turkey \\ ***Bezmialem Vakif University Faculty of Medicine, Department of Pediatric Hematology and Oncology, istanbul, Turkey
}

\section{Abstract}

The Freeman-Sheldon syndrome (FSS) (whistling face) is a congenital autosomal dominant disease (rarely described in its autosomal recessive form) characterized by small "whistling" mouth, a flat masklike face, joint contractures (commonly involving the fingers and hands) and underdevelopment of the nasal cartilage. Other clinical features include full forehead, deep set eyes, epicanthal folds, high palate, $\mathrm{H}$-shaped cutaneous dimpling on the chin, ulnar deviation of the hands, seizures, and dislocation of the hip. A 10-day-old male newborn was admitted to our neonatal intensive care unit with jaundice and hyperthermia. He had fever of $42.5^{\circ} \mathrm{C}$, small whistling mouth, a flat mask-like face, joint contractures of the fingers, and ulnar deviation of the hands. The parents were consanguineous and one of the boys died when he was 1 years old due to intracranial hemorrhage. To our knowledge, there have been more than 60 cases diagnosed with FSS. This is the first reported case of Freeman-Sheldon syndrome associated with hemophilia A and the second case of FSS associated with fever without anesthesia.

Keywords: Whistling face syndrome, newborn, hyperthermia, hemophilia
Öz

Freman-Sheldon sendromu, Islık çalar şekilde küçük ağız, maske şeklinde yüz, eklem kontraktürleri (özellikle el ve parmaklarda), gelişmemiş burun kıkırdağı ile karakterize otozomal dominant (nadiren otozomal resesif olgular da bildirilmiştir geçiş gösteren bir hastalıktır. Diğer klinik bulguları; geniş alın, derin yerleşimli gözler, epikantal kıvrımlar, yüksek damak, H şeklinde çukurlaşan çene, ellerin ulnar deviasyonu, nöbetler ve kalça çıkığıdır. Yenidoğan yoğun bakım ünitemize 10 günlük erkek hasta sarılık ve yüksek ateş nedeniyle yatırıldı. Hastamızın $42,5^{\circ} \mathrm{C}$ ateşi, ıslık çalar şekilde küçük ağzı, maske şeklinde yüzü, parmaklarda eklem kontraktürleri, ellerinde ulnar deviasyonu vardı. Anne baba akraba idi ve 1 yaşında bir erkek çocuklarını intrakraniyal hemoraji nedeniyle kaybetmişlerdi. Ingilizce literatür taramalarında 60 olgudan fazla Freman-Sheldon sendromu olgusu bulunduğu görülmekle birlikte olgumuz hemofili A ile birlikteliği olan ilk, anestezi almadan hipertermi görülen ikinci olgudur.

Anahtar Sözcükler: Islık çalan yüz sendromu, yenidoğan, hipertermi, hemofili

\section{Introduction}

Freeman-Sheldon syndrome (FSS) is a congenital autosomal dominant disease (rarely described in its autosomal recessive form) characterized by small "whistling" mouth (whistling face), joint contractures, commonly involving the fingers and hands, and underdevelopment of the nasal cartilage which makes the face look flat and mask-like. Other clinical features include full forehead, deep set eyes, epicanthal folds, high palate, $\mathrm{H}$-shaped cutaneous dimpling on the chin, ulnar deviation of the hands, seizures, and dislocation of the hip (1). The features of this syndrome is secondary to increasing tone of muscles $(1,2)$.

FSS was first described in 1938 (OMIM 277720); less than 100 cases have been reported in the literature since
Address for Correspondence/Yazıșma Adresi: Süleyman Bayraktar Haseki Training and Research Hospital, Department of Pediatrics, İstanbul, Turkey Phone: +90 2125294400 E-mail: bsuleyman@hotmail.com

Received/Geliş Tarihi: 24 February 2016 Accepted/Kabul Tarihi: 20 March 2016 This study was presented in $20^{\text {th }}$ National Neonatology Congress. 'Copyright 2016 by The Medical Bulletin of
Haseki Training and Research Hospital The Medical Bulletin of Haseki published by Galenos Yayınevi. ๑Telif Hakkı 2016 Haseki Eğitim ve Araştırma Hastanesi Haseki Tıp Bülteni, Galenos Yayınevi tarafından basılmışıır. 
then $(1,3)$. Here, we describe a patient diagnosed as having FSS with hemophilia A. To our knowledge, this is the first reported case in the literature.

\section{Case}

A 10-day-old male baby was transferred to our neonatal intensive care unit (NICU) with hyperbilirubinemia. The baby was born at home. The labor was uneventful. The parents took him to a local hospital for feeding problems. At admission, he had fever $\left(42.5^{\circ} \mathrm{C}\right.$-axillary), icteric skin and ecchymotic areas on both forearms. He was the fifth child of consanguineous parents. His mother had 6 brothers, all of whom had hemophilia A. One of her male children died at 1 year of age because of an intracranial hemorrhage due to hemophilia A. He, like our case, had also had fever which was thought to be a central fever due to intracranial hemorrhage. It is possible that he also had FSS and hemophilia A. In addition, the baby's uncles had dimples on their chins which were the sign of FSS.

On examination, the baby's face seemed dysmorphic. He had whistling face including small puckered mouth, thin-pursed lips, long philtrum, prominent cheeks, and broad forehead. The upper limbs had camptodactyly with ulnar deviation of fingers and wrists with contracture of thumbs in adduction (Figure 1,2). A sepsis work-up was done with the following results: white blood cell: 9600/ $\mathrm{mm}^{3}$ hemoglobin: $13.2 \mathrm{mg} / \mathrm{dL}$, platelet: $329.000 /$ $\mathrm{mm}^{3}$, polymorphonuclear leukocyte: $54 \%$, lymphocyte: 40\%, monocyte: $6 \%$ and C-reactive protein: $0.4 \mathrm{mg} / \mathrm{dL}$ (negative). Blood, urine and cerebrospinal fluid cultures were negative.

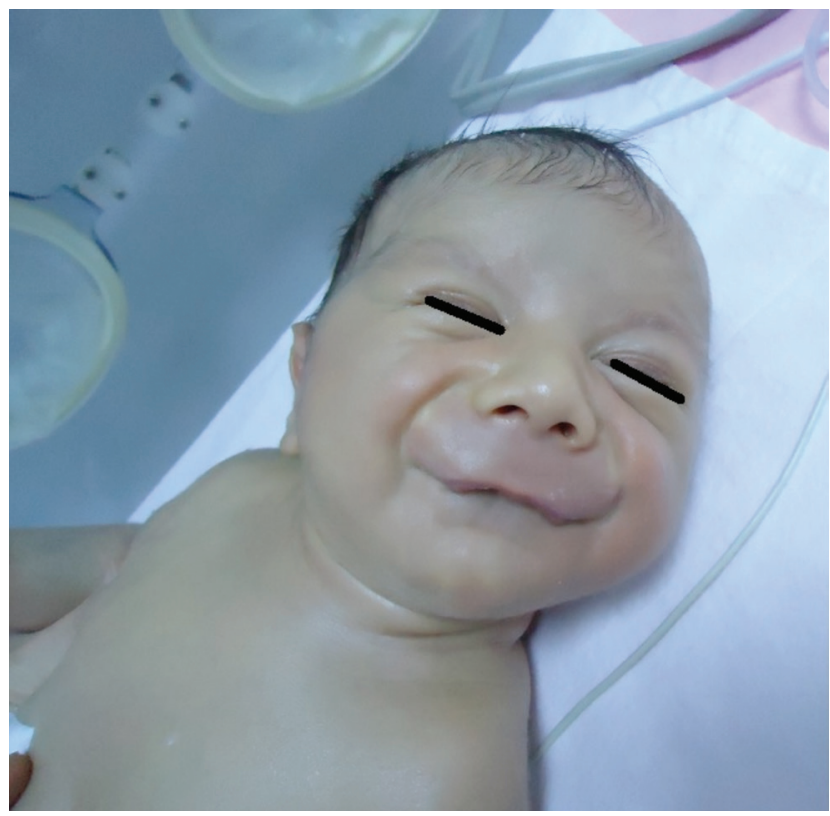

Figure 1. Typical Whistling face of the patient
Because of the echymotic areas on his skin and the family history of hemophilia A, we looked at prothrombin time, activated partial thromboplastin time, international normalized ratio and factor 8 and the results were: 20.8 $\mathrm{sec},>120 \mathrm{sec}, 1.75$, and $0.7 \%$, respectively. Abdominal ultrasonography revealed mild hepatomegaly. His cranial magnetic resonance imaging (MRI) disclosed delayed myelination and hypoxic-ischemic encephalopathy. Cervical MRI showed bulging on C5-6 and C6-7. During the follow up, he had cyclic fever of up to $38.5^{\circ} \mathrm{C}$ every 2 or 3 days. He had persistent tonic seizures at admission treated with phenobarbital and phenytoin. The baby had sucking and swallowing disorders and was fed via orogastric tube. He was discharged from the NICU when he was 30 days old still on orogastric tube feeding. At the 4 months of age, he was admitted to the hospital with severe respiratory distress and died on the $7^{\text {th }}$ days of hospitalisation.

\section{Discussion}

FSS is known as distal arthrogryposis type 2A. Most of the features are secondary to increased muscle tone. The known genetic etiologies of distal arthrogryposis syndromes involve abnormalities of the contractile apparatus of fast-twitch myofibers. The children with FSS are recognized by the characteristic facial appearance and the associated joint abnormalities. The syndrome has three characteristics: deformity of the face, camptodactyly with ulnar deviation of the fingers and/or wrists and bilateral clubfoot. As babies, they have feeding difficulties (e.g., poor suckling, vomiting and regurgitation), failure to thrive, and respiratory problems. Complicating their condition are recurrent respiratory infections (2). There may be early mortality related to aspiration. Difficulties with speech and oral hygiene can be a problem. Speech therapy is beneficial. Microcephaly and mental retardation have been reported in about one third of these children (3). Neuroimaging abnormalities include cerebral-cerebellar and brain stem atrophy, enlarged cisterna magna and interhemispheric fissure, ventricular dilatation, and cerebral venous thrombosis (4-6). Our patient had abnormal myelination and hypoxic ischemic encephalopathy.

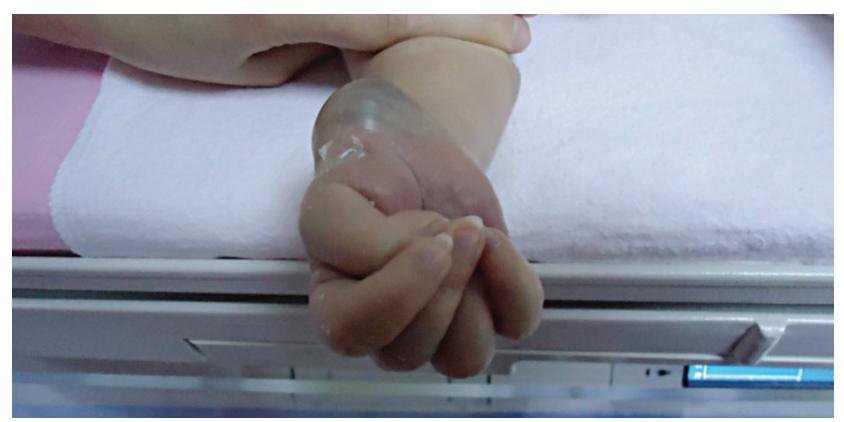

Figure 2. Ulnar deviations of the fingers and the hematoma of the wrist 
Parents are given genetic counseling. Prenatal diagnosis is possible by level 2 ultrasound scan. In the second trimester of pregnancy, facial and limb abnormalities can be detected (7-9). Vimercati et al. (7) have prepared a standard chart for fetal lip width to detect these abnormalities. Individuals with FSS should be counseled that recurrent risk for FSS is $50 \%$ (1). Most cases of FSS in the literature were reported as sporadic, but it can also be in a form of autosomal recessive or X-linked recessive patterns (2). In addition, mutations in the embryonic myosin heavy chain (MYH3) gene at 17p-13.1-pter have been showed (10).

The treatment of FSS includes surgical correction of skeletal deformities (surgical procedures are performed mostly on the limbs) and improving respiratory function. The risk of malignant hyperthermia and postoperative pulmonary complications are very high in these patients (11). The surgical procedures are done mostly on the limbs. Difficulty with intubation is a common complication, with hyperpyrexia reported in FSS patients after anesthesia. It has been suggested that hyperpyrexia is due to induction of the anesthetic agents because of myopathy (2). Our patient is the second case reported in the literature who had hyperthermia without anesthesia (12). His hyperpyrexia was characterized by a fever of $38.3^{\circ} \mathrm{C}$ to $42.5^{\circ} \mathrm{C}$ once in a day persisting for two weeks.

This is the first case of FSS associated with hemophilia A in the literature and the second case of FSS associated with fever without anesthesia. We report this case to raise awareness of the neonatologists and geneticists about this rare syndrome and associated disorders as a result of consanguineous marriages.

\section{Ethics}

Informed Consent: It was taken.

Peer-review: Internally peer-reviewed.

\section{Authorship Contributions}

Concept: Bilge Tanyeri Bayraktar, Süleyman Bayraktar. Design: Bilge Tanyeri Bayraktar, Süleyman Bayraktar. Data Collection or Processing: Bilge Tanyeri Bayraktar, Süleyman Bayraktar, Hüseyin Arslan, Fatma Betül Çakır. Analysis or Interpretation: Bilge Tanyeri Bayraktar, Süleyman Bayraktar, Hüseyin Arslan, Fatma Betül Çakır. Literature Search: Bilge Tanyeri Bayraktar, Süleyman Bayraktar. Writing: Bilge Tanyeri Bayraktar, Süleyman Bayraktar.
Conflict of Interest: No conflict of interest was declared by the authors.

Financial Disclosure: The authors declared that this study received no financial support.

\section{References}

1. Jones KL. Freeman Sheldon (Whistling Face Syndrome). In: Jones $\mathrm{KL}$, editor. Smith's Recognizable Patterns of Human Malformation. 7th ed. Philadelphia: PA: Elsevier Saunders Company; 200. p. 242.

2. Stevenson DA, Carey JC, Palumbos J, et al. Clinical characteristics and natural history of Freeman-Sheldon syndrome. Pediatrics 2006;117:754-62.

3. Gurjar V, Parushetti A, Gurjar M. Freeman-sheldon syndrome presenting with microstomia: a case report and literature review. J Maxillofac Oral Surg 2013;12:395-9.

4. Zampino G, Conti G, Balducci F, et al. Severe form of FreemanSheldon syndrome associated with brain anomalies and hearing loss. Am J Med Genet 1996;62:293-6.

5. Al-Sajee DM, Habbal OA, Reyes ZS. Freeman-Sheldon syndrome with cerebral venous thrombosis: is it a coincidence? J Postgrad Med 2010;56:37-9.

6. Schrander-Stumpel C, Fryns JP, Beemer FA, et al. Association of distal arthrogryposis, mental retardation, whistling face, and Pierre Robin sequence: evidence for nosologic heterogeneity. Am J Med Genet 1991;38:557-61.

7. Vimercati $A$, Scioscia $M$, Burattini $M G$, et al. Prenatal diagnosis of Freeman-Sheldon syndrome and usefulness of an ultrasound fetal lip width normogram. Prenat Diagn 2006;26:679-83.

8. Hegde SS, Shetty MS, Rama Murthy BS. Freeman-Sheldon syndrome-prenatal and postnatal diagnosis. Indian J Pediatr 2010;77:196-7.

9. Robbins-Furman $P$, Hecht JT, Rocklin $M$, et al. Prenatal diagnosis of Freeman-Sheldon syndrome (whistling face). Prenat Diagn 1995;15:179-82.

10. Toydemir RM, Rutherford A, Whitby FG, et al. Mutations in embryonic myosin heavy chain (MYH3) cause FreemanSheldon syndrome and Sheldon-Hall syndrome. Nat Genet 2006;38:561-5.

11. Ferrari $D$, Bettuzzi $C$, Donzelli O. Freeman-Sheldon syndrome. A case report and review of the literature. Chir Organi Mov 2008;92:127-31.

12. Altunhan $H$, Annagur A, Ertugrul $S$, et al. Freeman-Sheldon (whistling face) syndrome with hyperpyrexia in the newborn: case report. Genet Couns 2010;21:347-51. 